\title{
Use of enzymes to enhance oil recovery during aqueous extraction of Moringa oleifera seed oil
}

\begin{abstract}
Moringa oleifera seed oil was extracted using four different types of enzymes to obtain the most efficient extraction parameters. The enzymes used were Neutrase 0.8L (neutral protease), Termamyl 120L, type L (a-amylase), Pectinex Ultra SP-L (pectinase) and Celluclast 1.5L FG (cellulase). These were used either separately or in combination. Individually, Neutrase was found to be the most effective, followed by Termamyl, Celluclast and Pectinex. A combination of the four enzymes was found to be more effective than used separately, with $74 \%$ oil recovery. Percent oil recovery for individual enzymes under optimal conditions and with $\mathrm{pH}$ adjusted to the individual enzyme's optimum $\mathrm{pH}$ were 71.9, 64.8, 62.6 and 56.5 for Neutrase, Termamyl, Celluclast and Pectinex, respectively. Neutrase, Pectinex and the combination of all the four enzymes at $2 \%(\mathrm{v} / \mathrm{w})$ were found to perform best at $45 \mathrm{C}$, while Termamyl and Celluclast were best at $60 \mathrm{C}$. The physical and chemical properties of the extracted oils such as iodine value (IV) (66.0-67.2 g iodine/100 g oil), free fatty acid (FFA) content (1.13-1.25 as \% oleic acid), complete melting points (MPs) (18.619.1C) and viscosities (83.1-85.0 cP) except the color were not significantly affected (P 0.05) by the type of enzyme used in
\end{abstract}

